\title{
Insecticidal effect of the ethanol extract of Baccharis dracunculifolia (Asterales: Asteraceae)
}

\author{
Elizabete Maria da Silva ${ }^{1}$, Antonia Railda Roel ${ }^{1}$, Karla R. A. Porto ${ }^{2}$, Matheus Escobar Falco ${ }^{3}$ \&
} Rosemary Matias ${ }^{4}$

1. Pós-Graduação em Ciências Ambientais e Sustentabilidade Agropecuária, Universidade Católica Dom Bosco UCDB. Av. Tamandaré, 6000 - Jardim Seminário, Campo Grande - MS, 79117-900, Brasil.

2. Pós-graduação Rede Pro Centro-Oeste, UFMS. Av. Costa e Silva, s/n - Cidade Universitária, Campo Grande - MS, 79070-900. Brasil.

3. Agronomia. Universidade Católica Dom Bosco - UCDB. Av. Tamandaré, 6000 - Jardim Seminário, Campo Grande MS, 79117-900. Brasil.

4. Pós-Graduação em Meio Ambiente e Desenvolvimento Regional, Universidade Anhanguera - Uniderp, Rua Ceará, 333 - Miguel Couto, Campo Grande - MS, 79005-000. Brasil.

E-mails: dasilvabete@yahoo.com.br; arroel@ucdb.br; portokra@hotmail.com; matheusfalco.agro@gmail.com; rosematias@uniderp.edu.br

$$
\text { Received 21-VII-2016. C Corrected 25-I-2017. } \quad \text { Accepted 28-II-2017. }
$$

\begin{abstract}
Insecticides from plants have been studied as an alternative in agricultural production and in vector control of human diseases. The use of botanical insecticides may cause mortality in different stages, slow growth, infertile adults and decrease in viability of insect eggs. This study aimed to analyze the insecticidal potential of ethanol extract of Baccharis dracunculifolia DC, on Spodoptera frugiperda Smith, 1797 (Noctuidae) and Aedes aegypti L., 1762 (Culicidae). The botanical material was collected and prepared on February $8^{\text {th }}, 2011$ on the Fazenda Escola Três Barras (20³3’37.44043”' S - 54³2’10.3824” W), Campo Grande, MS. The ethanol extract was prepared from dried leaves obtained of adult plants in a vegetative state at the Chemistry Laboratory of Anhanguera University-Uniderp. The experiments of biological activities were conducted at the Entomology Laboratory of the Catholic University Don Bosco, in a controlled environment with an average temperature of $25^{\circ} \mathrm{C}$ and photoperiod $12 \mathrm{hr}$. Experiments with S. frugiperda were conducted from August to October 2014. The collection of $A$. aegypti eggs was made in January 2014 and the treatments were done from March $10^{\text {th }}$ to $17^{\text {th }}, 2014$. In the development of S. frugiperda the extract caused effect on caterpillars subjected to treatment at one and 10 days. The larval stage proved to be longer at both ages and pupal weight reduced at 10 days, as well as increased mortality at one day, when incorporated concentration $0.2 \%$ into diet. The variables studied were mortality, larval duration, pupal weight, number and viability of the eggs. The bioassay used $A$. aedes third instar, 25 larvae per concentration, at four replicates. Parameters analysed for sublethal doses were pupal and larval, mortality, length larval and young (larva + pupa) the ethanol extract at concentrations $0.5 \mathrm{mg} \cdot \mathrm{mL}^{-1}$ and $0.25 \mathrm{mg} \cdot \mathrm{mL}^{-1}$. The extract resulted in deleterious effect on the development of caterpillars undergoing treatment in larvae of one and 10 days of age, the larval stage stretching, lower pupal weight in caterpillars 10 days and higher mortality in the group with one day of life. It did not interfere with the viability of eggs. In the life cycle of $A$. aegypti, the extract of $B$. dracuncufolia at the studied concentrations caused delay in the development of larval and pupal stages, and inhibited the emergence of adults in $85 \%$ and $70 \%$. In laboratory conditions it can be said that the ethanol extract of $B$. dracunculifolia has a potential insecticide effect for both species of insects. Rev. Biol. Trop. 65 (2): 517-523. Epub 2017 June 01.
\end{abstract}

Key words: sustainable agriculture, botanical insecticide, Spodoptera frugiperda, vector disease control, corn pest control. 
The environmental damage caused by humans has become of increasingly concern, raising a lot of discussion on agrarian and urban sustainability. The numerous environmental issues and their consequences have led to a search for economically viable alternatives that protect the environment and human health.

Among the many insect pests which attack crops in the American continent, Spodoptera frugiperda (Smith, 1797) (Noctuidae), is known as corn plant whorl caterpillar and fall armyworm. In Brazil, it attacks several crops such as horticulture, grasses and recently, it has also become an important pest in cotton plantations (Martinelli, Barata, Zucchi, DeCastroSilva-Filho, \& Omoto, 2006). However, it is in the corn crop that it stands out as the main pest, coming to totally destroy the whorl of corn plants.

Another important aspect to public health in Brazil is the insect Aedes aegypti L. (Linn, 1762) (Culicidae), vector of Dengue, Chikungunya and Zika virus, with recurring situations of seasonal epidemics. It has become undeniable to discuss the need to establish ecological and systematic integrated strategies, with the replacement of exclusive use of chemicals. Thus, health surveillance should incorporate interinstitutional practices with social, environmental and health actions (Pignati, Oliveira, \& Silva, 2014; Guirado \& Bicudo, 2009).

Plant-based insecticides have been studied as an alternative in agricultural production and in vector control of human diseases. The use of botanical insecticides may cause mortality in different stages, slow growth, infertile adults and decrease in viability of insect eggs. It is, therefore, an environmentally feasible control alternative when observing the whole cycle and continuity of other generations (Isman, 2006). As renewable natural resource, plant-based active substances are generally less harmful to the environment, which tend to decrease production costs. Resistance to plants of active ingredients is rare, due to the complexity of their molecules (Barreto, 2005; Knaak, Tagliari, Machado, \& Fiuza, 2012).
Popularly known in Brazil as carqueja, vassoura or vassourinha, Baccharis has high socioeconomic impact in the states of São Paulo, Paraná, Santa Catarina and Rio Grande do Sul for its cultivation and medicinal use. Among the chemical compounds already described are the flavonoids, clerodanes and labdanes, auranas, triterpenoids, germaceno, cumaric acids, sesquiterpenes phenylpropanoids (Cuzzi, Link, Vilani, Sartori, \& Onofre, 2012). A study on essential oils extracted from $B$. dracunculifolia, found that it is also used as an insecticide to control the maize weevil (Sitophilus zeamais) and brown beetle (Tribolium castaneum). This method is considered effective, without leaving residues that harm the health of consumers (Mossi, A. J. et al., 2013).

Thus, the objective was to study the insecticide potential of B. dracuncufolia (Asteraceae) on insects of medical and agricultural importance, very common in Brazil, such as $A$. aegypti and $S$. frugiperda, in laboratory conditions, observing the effects on parameters, mortality, longevity and fertility.

\section{MATERIALS AND METHODS}

Collection and identification of botanical materials: The botanical materials collected and prepared on February $8^{\text {th }}, 2011$, on the Fazenda Escola Três Barras (20³3'7.44043" S - 5432'10.3824” W), Campo Grande. The ethanol extract (w/v) was prepared from dried leaves obtained from adult plants in a vegetative state, at the Chemistry Laboratory of Anhanguera University-Uniderp, using ethanol, and absolute ethyl alcohol (Chemco). A sample was used for the deposit of excisata, at the Herbarium of Anhanguera UniversityUniderp, identified by M.Sc. Eloty Justina Dias Schleder. The experiments of biological activities were conducted at the Entomology of Dom Bosco Catholic University, in controlled room with temperature of $25^{\circ} \mathrm{C}$ and photoperiod of $12 \mathrm{hr}$.

Bioassay with S. frugiperda: The experiment with $S$. frugiperda was conducted 
from August to October 2014, with larvae of one and 10 days (two ages); we used 50 larvae per treatment. The larvae, as being cannibals, were individually reared in flat-bottomed glass diet tubes $(2.5 \mathrm{~cm}$ diameter $\times 8.5 \mathrm{~cm}$ height).

For the treatment, ethanolic extract of $B$. dracunculifolia $0.2 \%$, was incorporated into artificial diet by Greene, Leppla and Dickerson (1976), modified by Parra (2001). For the control, the larvae were fed on a diet with no addition of extract. The $24 \mathrm{hr}$ pupae were weighted on an eletrônica digital Gehaka (BG-4400) precision scale in grams, sexed.

The evaluated variables were: mortality and larval duration, pupal weight, number and egg viability. To analyze the position and viability of eggs, five couples were formed per treatment. For each treatment, the emerged adults were individually placed in PVC cages, which were lined on the sides with filter paper, capped at the top with organza type fabric and the bottom had plastic plate lined with filter paper. The couples were fed honey $10 \%$ solution, changed every two days, provided in glasses $(4.5 \mathrm{~cm}$ height and $2.0 \mathrm{~cm}$ diameter) with cotton.

The egg masses were daily cut from the filter paper and placed on Petri of $1.8 \mathrm{~cm}$ height and $6.0 \mathrm{~cm}$ in diameter. For the total counting of eggs a stereomicroscope was used. The number of hatched larvae was counted on a daily basis.

The experimental design was completely randomized. The data, larval duration, pupal weight, posture and egg viability were subjected to analysis of variance by $\mathrm{F}$ test and means were compared by Tukey test $1 \%$ probability using the program ASSISTAT Beta 7.7 (Silva, 2016). Mortality was assessed with the percentage obtained between the number of initial larvae and the number of formed pupae.

Bioassay with $A$. aegypti: The collection of $A$. aegypti eggs was made in January 2014, at Zoonoses Control Center (CCZ) in the city of Campo Grande, MS. The eggs, obtained from the laboratory stock, were allowed to mature for one week. After this procedure, they were subjected to hatch in dechlorinated water at a $\mathrm{pH}$ between 6.5 and 7 . The larvae were separated by age for toxicity testing and monitoring changes in the cycle.

Third instar larvae were used, numbering 25 individuals per $25 \mathrm{~mL}$ solution, each. The treatments were done from March $10^{\text {th }}$ to $17^{\text {th }}, 2014$. The treatments were $0.5 \mathrm{mg} \cdot \mathrm{mL}^{-1}$ and $0.25 \mathrm{mg} \cdot \mathrm{mL}^{-1}$ of the ethanol extract of $B$. dracunculifolia in quadruplicate. Meanwhile, negative control (white) and positive control (Rotenone) were performed according to a methodology adapted by Laranja, Manzato and Bicudo (2006).

The parameters analyzed were larval and pupal mortality, larval length and larval+pupal length (young stage), adult emergence. All data were subjected to one way Anova and Tukey test at $5 \%$ probability through software ASSISTAT Beta 7.7 (Silva, 2016). Mortality data were turned into percentage.

\section{RESULTS}

Larval mortality of $S$. frugiperda in control without addition of treatment was $13 \%$. The mortality after treatment with the extract of $B$. dracunculifolia at $0.2 \%$ that started with oneday larvae was $35 \%$, whereas the treatment that started with 10-day larvae resulted in $29 \%$ mortality (Fig. 1).

Larval duration in control was 24 days, different from the one obtained for larvae fed of 10 days and one day old, with 28 and 26 days, respectively. The results point to the deleterious effect of the product in insect growth, especially for the 10 days old larvae treatment (Table 1).

In the analysis of pupal weight of larvae treated with the extract of $B$. dracunculifolia there was less weight for the 10 day group larvae, in relation to the control and treatment with one-day larvae (Table 1).

The B. dracunculifolia extract in A. aegyp$t i$ showed deleterious effects on development and mortality. As for larval length, there was no difference between the concentrations of 0.5 $\mathrm{mg} \cdot \mathrm{mL}^{-1}$ and $0.25 \mathrm{mg} \cdot \mathrm{mL}^{-1}$ (7 days), although 


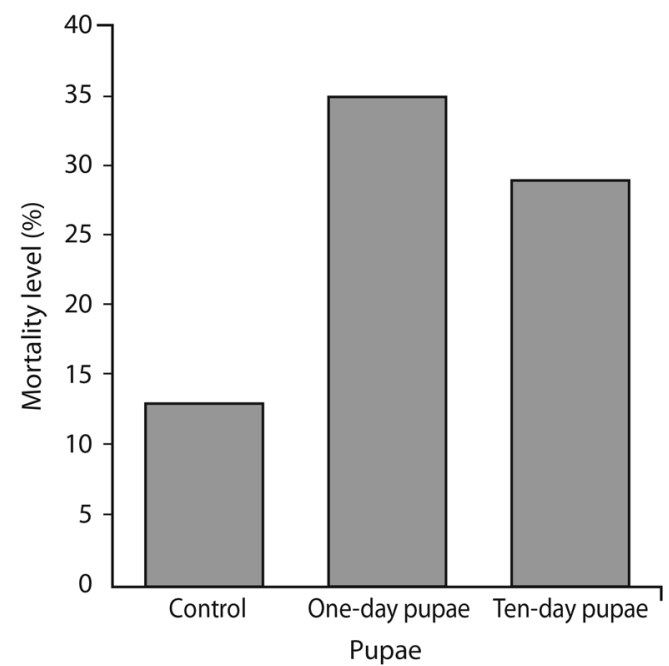

Fig. 1. Larval stage mortality of S. frugiperda fed artificial diet with ethanol extract of B. dracunculifolia at $0.2 \%$.

different from the control (5 days). The changes became more significant when observing the duration of the young (pupal + larvae) at concentrations of $0.5 \mathrm{mg} \cdot \mathrm{mL}^{-1}$ and 0.25 mg. $\mathrm{mL}^{-1}$, extending from to about 11 days, when compared to the control lasting between seven to eight days. This indicates problems in the development, which was confirmed in the pupal mortality (Table 2).

The extract caused low mortality on $A$. aegypti larvae in standard test by reading mortality after $24 \mathrm{hr}$ of exposure, with a mortality rate lower than $50 \%$ even at the highest concentrations 1 and $0.5 \mathrm{mg} \cdot \mathrm{mL}^{-1}$. Therefore, effects of sub-lethal concentrations as $0.5 \mathrm{mg}$. $\mathrm{mL}^{-1}$ and $0.25 \mathrm{mg} \cdot \mathrm{mL}^{-1}$ were observed along all the development. Mortality of 70 to $85 \%$ was observed in pupae, in treatments 0.5 and 0.25 mg. $\mathrm{mL}^{-1}$, respectively. In the control group, all larvae produced adults under treatment, resulting in only 30 and 15 adults produced respectively, in 0.5 and $0.25 \mathrm{mg} \cdot \mathrm{mL}^{-1}$ treatments (Table 2).

\section{DISCUSSION}

The extract of B. dracunculifolia at 0.2 $\%$ concentration had little toxic effect on the larval stage of $S$. frugiperda, mainly in one day larvae. This is in accordance with the results achieved by Rodríguez and Vendramim (1996) that highlighted greater efficiency of insecticidal plants in insect pests that ingest the insecticide treatment at the beginning of the larval stage.

The greatest effect within cycle extension in 10-day larvae may have been determined by the fact that they are already adapted to the diet without the extract until the tenth day of development. Thus, the variable duration of the larval stage may be associated with the age of larvae.

The extension in the larval stage points to trouble completing the development, which was observed for both $A$. aegypti and S. frugiperda. This is proven by the deleterious effects in the pupal stage, such as high mortality in $A$. aegypti and reduced pupal weight for $S$. frugiperda. Regarding adulthood, there was reduction in the formation of $A$. aegypti adults and in the number of eggs per female for $S$. frugiperda,

TABLE 1

Effect of Baccharis dracunculifolia extract at $0.2 \%$ in artificial diet on Spodoptera frugiperda

\begin{tabular}{lcccc}
\multicolumn{1}{c}{ Treatment } & $\begin{array}{c}\text { Larval duration } \\
\text { (days) }\end{array}$ & $\begin{array}{c}\text { Pupal weight } \\
\text { (grams) }\end{array}$ & $\begin{array}{c}\text { Number of } \\
\text { eggs/ female }\end{array}$ & $\begin{array}{c}\text { Egg viability } \\
(\%)\end{array}$ \\
Control & $24 \mathrm{C}^{* *}$ & $0.27 \mathrm{~A}^{* *}$ & $576 \mathrm{~A}^{\mathrm{ns}}$ & 59.0 \\
Diet with B. dracunculifolia in one day pupae & $26 \mathrm{~B}^{* *}$ & $0.26 \mathrm{~A}^{* *}$ & $292 \mathrm{~B}^{\mathrm{ns}}$ & 46.4 \\
Diet with B. dracunculifolia in 10 day pupae & $28 \mathrm{~A}^{* *}$ & $0.19 \mathrm{~B}^{* *}$ & $393 \mathrm{~B}^{\mathrm{ns}}$ & 38.0 \\
C V\% & 7.43 & 17.38 & 28.43 & \\
\hline
\end{tabular}

** Analysis using Tukey test, $\mathrm{F}$ was significant at $1 \%$ probability $(\mathrm{p}<0.01)$.

ns Analysis using Tukey test, F was no significant ( $\mathrm{p}>=0.05)$. 
TABLE 2

Effect of Baccharis dracunculifolia extract in the development and mortality of Aedes aegypti

\begin{tabular}{lccccc}
\multicolumn{1}{c}{ Sample } & $\begin{array}{c}\text { Larval duration } \\
\text { (days) }\end{array}$ & $\begin{array}{c}\text { Larval } \\
\text { mortality (\%) }\end{array}$ & $\begin{array}{c}\text { Young (larva+pupa) } \\
\text { duration (days) }\end{array}$ & $\begin{array}{c}\text { Pupal } \\
\text { mortality (\%) }\end{array}$ & $\begin{array}{c}\text { Adults emerged } \\
(\%)\end{array}$ \\
Extract at $0.5 \mathrm{mg} \cdot \mathrm{mL}^{-1}$ & $7 \mathrm{~B} *$ & 0.0 & $12 \mathrm{~B}$ & 70 & 30 \\
Extract at $0.25 \mathrm{mg} \cdot \mathrm{mL}^{-1}$ & $7 \mathrm{~B} *$ & 2.5 & $11 \mathrm{~B}^{*}$ & 85 & 15 \\
Control & $5 \mathrm{~A}$ & 0.0 & $8 \mathrm{~A}$ & 0.0 & 100 \\
\hline
\end{tabular}

* Means followed by the same letter are not statistically different from each other by Tukey test at $5 \%$ probability $(\mathrm{p}<0.05)$.

causing consequently a reduction of growth potential in insects of the next generation.

The extension of the larval stage in larvae of agricultural pests through the use of insecticide plants has also been described by Bruce, Gounou, Chabi-Olaye, Smith and Schulthess (2004), and by Tanzubil and McCaffery (1990), among others. They highlighted the presence of growth inhibitors in certain insecticidal plants. Such effect may be related to difficulties in converting food in ingestion, and digestion due to the presence of the insecticide.

Torres, Barros and Oliveira (2001) observed no pupal weight change in studies with moth, Plutella xylostella L. (Plutellidae), fed cabbage disc (Brassicaoleracea) immersed in extracts of Azadirachta indica (Meliaceae). De-Ling, Gordh and Zalucki (2000) also reported no change in pupal weight when analyzing Helicoverpa armigera Hübner (Noctuidae) which received neem oil-based insecticide treatment. The same was observed in this experiment when started with one-day larvae.

However, lower pupal weight after treatment was described by Rodriguez and Vendramim (1996) in S. frugiperda treated with vegetable insecticides, including neem. This effect was also observed by Fernandes (2012) when analyzing the purple pinion, Jatropha gossypifolia L. (Euphobiaceae), toxicity on $S$. frugiperda. This effect was also observed in this experiment in 10-day larvae which started treatment. According to these authors, low pupal weight may be related to the presence of growth inhibitors, as well as difficulty in converting the food due to the presence of insecticide factor in the larval stage. Therefore, there may be a correlation between pupal weight and larval development. Larvae which started treatment at 10 days, had longer larval period and more feeding difficulties alongside, thus justifying lower pupal weight.

In studies by Lemos, Barros, Sousa, Bastos and Andrade (2007), the chemical composition $B$. dracunculifolia revealed the presence of acid derivatives and cinnamic flavonoids. Although reports on cinnamic flavonoids are almost exclusively for medical use, Dixon and Steele (1999) emphasize that flavonoids, in general, play a role in plant defense against aggressors like insects. These have also deterrent, repellent or toxic properties to soybean insect pests, according to Hoffmann-Campo, Harborne and Mccaffery (2001).

Other species of Asteraceae family were cited as having active ingredients of $A$. aegypti, such as the essential oil of Tagetes minuta L (Lima, Chiaravalloti Neto, Macoris, Zuccari \& Dibo, 2009) and the crude extract of Artemisia annua on A. aegypti, Anopheles sinensis and Culex quinquefasciatus. Thus, indicating that the family has the potential for vector control (Cheah, Tay, Chan, \& Jaal, 2013). Gleiser, Bonino and Zygadlo (2011) also mention the essential oils of Baccharis salicifolia among several plant species, with active repellent ingredients against $A$. aegypti.

The results indicated the insecticide potential of ethanol extract of leaves of $B$. dracunculifolia for both insects $A$. aegypti and $S$. frugiperda. The return of insecticide products of plant origin, practiced for thousands of years, can be still an alternative for the control of insect vectors of diseases and agricultural 
pests, as well as provide subsidies for the synthesis of active molecules.

The ethanol extract of $B$. dracunculifolia added to the diet of $S$. frugiperda from newborn or 10 days of age increased in larval stage duration period. They decreased pupal weight only in 10 days of age larvae fed. They also decreased in number of eggs, but caused no effect on viability. The 0.5 and $0.25 \mathrm{mg} \cdot \mathrm{mL}^{-1}$ concentrations extracts, in tests of sub-lethal dosages, caused extension of 11 days in the young stage of $A$. aegypti when compared to control; it also caused pupal mortality, and reduction of the emerged adults.

\section{ACKNOWLEDGMENTS}

The support of Dom Bosco Catholic University (UCDB), the Federal University of Mato Grosso do Sul (UFMS), the Pantanal Research Center (CPP), the National Institute of Wetland Sciences and Technology (INAU) - through the Program National Institutes of Science and Technology of Brazil's National Council for Scientific and Technological Development, an agency of the Ministry of Science, Technology and Innovation (CNPq/MCTI), and the Mato Grosso do Sul Foundation for the Support and Development of Education, Science and Technology (FUNDECT).

\section{RESUMEN}

Efecto insecticida del extracto de etanol de Baccharis dracunculifolia (Asterales: Asteraceae). Los insecticidas de plantas han sido estudiados como una alternativa en la producción agrícola y el control de vectores de enfermedades humanas. El uso de insecticidas botánicos puede causar mortalidad en diferentes etapas, crecimiento lento, adultos infértiles y disminución en la viabilidad de huevos de insectos. Este estudio tuvo como objetivo analizar el potencial insecticida del extracto de etanol de Baccharis dracunculifolia DC, Spodoptera frugiperda Smith, 1797 (Noctuidae) y Aedes aegypti L., 1762 (Culicidae). Se recogió el material botánico y preparó el 8 de febrero 2011 en la Hacienda Escola Tres Barras. (20³3'37.44043'" S - 54³2'10.3824” W), Campo Grande, MS. El extracto de etanol se preparó a partir de hojas secas obtenidas de plantas adultas en estado vegetativo en el Laboratorio de Química de la Universidad Anhanguera -Uniderp.
Los experimentos de actividades biológicas se llevaron a cabo en el Laboratorio de Entomología de la Universidad Católica Don Bosco, en un ambiente controlado con una temperatura media de $25{ }^{\circ} \mathrm{C}$ y fotoperiodo de $12 \mathrm{hr}$. Los experimentos con $S$. frugiperda se llevaron a cabo de agosto a octubre 2014. La colección de huevos de A. aegypti se hizo en enero 2014 y los tratamientos se realizaron del 10 al 17 marzo 2014. En el desarrollo de S. frugiperda el extracto causa efecto sobre orugas sometidas a tratamiento de uno y 10 días. La etapa larval resultó ser más larga en ambas edades y el peso de la pupa se redujo a los 10 días; también, hubo aumento de la mortalidad en larvas de un día, cuando se incorporó la concentración $0.2 \%$ en la dieta. Las variables estudiadas fueron la mortalidad, la duración de las larvas, el peso de las pupas, y el número y viabilidad de los huevos. El bioensayo utilizó A. aedes en tercer instar, y 25 larvas por concentración, en cuatro repeticiones. Los parámetros analizados para las dosis sub-letal fueran las pupa y larva, mortalidad, duración de las larvas y jóvenes (+ larva pupa) en el extracto de etanol a concentraciones de $0.5 \mathrm{mg} \cdot \mathrm{mL}^{-1}$ y $0.25 \mathrm{mg} \cdot \mathrm{mL}^{-1}$. El extracto resultó en efecto perjudicial sobre el desarrollo de las orugas de uno y 10 días de edad, sometidas a los tratamientos, prolongación de la fase larvaria, menor peso de pupa en las orugas de 10 días y una mayor mortalidad en el grupo con un día de vida. No hubo interferencia con la viabilidad de los huevos. En el ciclo de vida de $A$. aegypti, el extracto de B. dracuncufolia en las concentraciones del estudio, causó retraso en el desarrollo de las etapas de larva y pupa, y se inhibió la emergencia de los adultos en un $85 \%$ y el $70 \%$. En condiciones de laboratorio, se puede decir que el extracto de etanol de B. dracunculifolia tiene potencial insecticida para ambas especies de insectos.

Palabras clave: agricultura sostenible, insecticida botánico, Spodoptera frugiperda, control de vectores de enfermedades, control de plagas de maíz.

\section{REFERENCES}

Barreto, C. F. (2005). Aedes aegypti-resistência aos inseticidas químicos e as novas alternativas de controle. Revista Eletrônica Faculdade Montes Belos, 2(1), 62-73.

Bruce, Y. A., Gounou, S., Chabi-Olaye, A., Smith, H., \& Schulthess, F. (2004). The effect of neem (Azadirachta indica A. Juss) oil on oviposition, development and reproductive potentials of Sesamia calamistis Hampson (Lepidoptera: Noctuidae) and Eldana saccharina Walker (Lepidoptera: Pyralidae). Agricultural and Forest Entomology, 3(6), 223-232.

Cheah, S. X., Tay, J. W., Chan, L. K. \& Jaal, Z. (2013). Larvicidal, oviposition, and ovicidal effects of Artemisia апnиа (Asterales: Asteraceae) against Aedes aegypti, Anopheles sinensis, and Culex quinquefasciatus (Diptera: Culicidae). Parasitology Research, 112(9), 3275-3282. Doi: 10.1007/s00436-013-3506-0 
Cuzzi, C., Link, S., Vilani, A., Sartori, C., \& Onofre, S. B. (2012). Endophytic fungi of the "vassourinha" (Baccharis dracunculifolia DC, Asteraceae). Revista Brasileira de Biociências, 10(2), 135.

De-Ling, M. A., Gordh, G., \& Zalucki, M. P. (2000). Biological effects of azadirachtin on Helicoverpa armigera (Hübner) (Lepidoptera: Noctuidae) fed on cotton and artificial diet. Australian Journal of Entomology, 39(4), 301-304. Doi: 10.1046/j.1440-6055.2000.00180.x

Dixon, R. A., \& Steele, C. L. (1999). Flavonoids and isoflavonoids - a gold mine for metabolic engineering. Trends in Plant Science, 4(10), 394-400. Doi: 10.1016/1360-1385(99)01471-5

Fernandes, T. S. (2012). Bioatividade de extratos aquosos de pinhão roxo Jatropha gossypiifolia L. sobre Spodoptera frugiperda (J. E. SMITH). (Dissertação de mestrado). Universidade Federal do Piauí. Teresina-PI, 58 P. Recuperado de http://www.leg.ufpi.br/subsiteFiles/ ppga/arquivos/files/Disserta $\% \mathrm{C} 3 \% \mathrm{~A} 7 \% \mathrm{C} 3 \% \mathrm{~A} 30 \% 20$ -The $\%$ C3\%B3filo.pdf

Gleiser, R. M., Bonino, M. A., \& Zygadlo, J. A. (2011). Repellence of essential oils of aromatic plants growing in Argentina against Aedes aegypti (Diptera: Culicidae). Parasitology Research, 108(1), 69-78. Doi: 10.1007/s00436-010-2042-4

Greene, G. L., Leppla, N. C., \& Dickerson, W. A. (1976) Velvetbean caterpillar: a rearing procedure and artificial medium. Journal of Economic Entomology, 69(4), 487-488.

Guirado, M. M, \& Bicudo, H. E. M. D. C. (2009). Alguns aspectos do controle populacional e da resistência a inseticidas em Aedes aegypti (Diptera, Culicidae). Bepa. Boletim Epidemiológico Paulista (Online), 6(64), 5-14.

Hoffmann-Campo, C. B., Harborne, J. B., \& Mccaffery, A. R. (2001) Pre-ingestive and post-ingestive effects of soya bean extracts and rutin on Trichoplusia ni growth. Entomologia Experimentalis et Applicata, 98(2), 181-194. Doi: 10.1046/j.1570-7458.2001.00773.x

Isman, M. B. (2006). Botanical insecticides, deterrents, and repellents in modern agriculture and an increasingly regulated world. Annual Review of Entomology, 51, 45-66. Doi: 10.1146/annurev.ento.51.110104.151146

Knaak, N., Tagliari, M. S., Machado, V., \& Fiuza, L. M. (2012). Atividade Inseticida de Extratos de Plantas Medicinais. Sociedade Entomológica do Brasil, Bio Assay, 7, 1-6. Doi: http://dx.doi.org/10.14295/ BA.v7.0.63

Laranja, A. T., Manzato, A. J., \& Bicudo, H. E. M. C. (2006).Caffeine effect on mortality and oviposition in successive generations of Aedes aegypti. Revista de Saúde Pública, 40(6), 1112-1117. http://dx.doi. org/10.1590/S0034-89102006000700022
Lemos, M., Barros, M. P., Sousa, J. P. B., Bastos, J. K., \& Andrade, S. F. (2007). Baccharis dracunculifolia, the main botanical source of Brazilian green propolis, displays antiulcer activity. Journal of Pharmacy and Pharmacology, 59(4), 603-608.

Lima, W. P., Chiaravalloti Neto, F., Macoris, M. L. G., Zuccari, D. A. P. C., \& Dibo, M. R. (2009). Estabelecimento de metodologia para alimentação de Aedes aegypti (Diptera-Culicidae) em camundongos swiss e avaliação da toxicidade e do efeito residual do óleo essencial de Tagetes minuta L (Asteraceae) em populações de Aedes aegypti. Revista da Sociedade Brasileira de Medicina Tropical, 42(6), 638-641. http:// dx.doi.org/10.1590/S0037-86822009000600005

Martinelli, S., Barata, R. M., Zucchi, M. I., DeCastroSilvaFilho, M., \& Omoto, C. (2006). Molecular variability of Spodoptera frugiperda (Lepidoptera: Noctuidae) populations associated to maize and cotton crops in Brazil. Journal of Economic Entomology, 99(2), 519526. Doi: 10.1017/S0007485307004944.

Mossi, A. J., Reichert, F. W., Scariot, M. A., Ecker, S., Campos, A., Meneguzzo, M., ... \& Treichel, H. (2013). 14417-Estudo do efeito repelente, inseticida do óleo essencial de Baccharis dracunculifolia DC no controle de insetos (Sitophilus zeamais) em grãos de milho armazenados. Cadernos de Agroecologia, $8(2), 1-5$.

Parra, J. R. P. (2001). Técnicas de criação de insetos para programas de controle biológico. Piracicaba: ESALQ/USP.

Pignati, W., Oliveira N. P., \& Silva A. M. C. (2014). Vigilância aos agrotóxicos: Quantificação do uso e previsão de impactos na saúde-trabalho-ambiente para municípios brasileiros. Ciências \& Saúde Coletiva, 12(19), 4669-4678. Doi: 10.1590/1413-812320141912.12762014

Rodriguez, C. H., \& Vendramim, J. D. (1996). Toxicidad de extractos acuosos de Meliaceae en Spodoptera frugiperda (Lepidoptera: Noctuidae). Manejo Integrado de Plagas, 42, 14-22.

Silva, F. A. S. (2015). ASSISTAT: Versão 7.7 beta. DEAGCTRN-UFCG- Atualizado em 01 de abril de 2015. Recuperado em 22 de abril de 2016 em http://www. assistat.com

Tanzubil, P. B., \& McCafery, A. R. (1990). Effects of Azadirachtin and aqueous neem seed extracts on survival, growth and development of the African Armyworm, Spodoptera exempta. Crop Protection, 9(5), 383-386. Doi: 10.1016/0261-2194(90)90012-V

Torres, A. L., Barros, R., \& Oliveira, J. V. (2001). Efeito de extratos Aquosos de Plantas no Desenvolvimento de Plutella xylostella (L.) (Lepidoptera: Plutellidae). Neotropical Entomology, 30(1), 151-156. 
